\title{
Impact of Retention of Slump on Growth of Ready Mixed Concrete
}

\author{
A. Nagaraju, P. Sandeep Kumar, M. Meena, S. Vijaya Bhaskar Reddy
}

\begin{abstract}
In these days the Ready Mixed Concrete (RMC) plants were giving a back bone support for construction and concrete industries. As the infrastructure increases, concrete demand also increasing proportionately due to huge benefits of concrete, consequently, number of ready mixed concrete plants were also increase proportionately to supply the concrete according to the demand. Those who are fed up with the site mixing and environmental problem associated with them, they are opting for RMC. The growth of RMC is increasing from metropolitan cities to villages. One of the key factors for the growth of RMC is retention of slump till reach the construction site by using super plasticizer. In the present study, the growth of RMC industry from 1990 's in India was presented. An experimental study was done on Slump retention capacity of concrete with fly ash, GGBS and lime Stone powder with $0.4 \%$ of admixture dosage.
\end{abstract}

Keywords :Growth of RMC, slump retention capacity, Super plasticizer, Ready mix concrete

\section{INTRODUCTION}

These days, as the constructions of structures are increases, due to huge advantages of concrete, demand of concrete also increases. However, lack of space constraints at the construction sites causes difficult to mix concrete. Consequently, the Ready Mixed concrete plants are become the emerging solution. The ready mixed concrete plants are make constructions of high rise buildings, within short space, saves the time of preparation of concrete, with better quality [1]. The Ready mixed concrete plant was stated at 1950's in India. However, in 1987 the first RMC plant was operated and from 1994, the commercial RMC has been growing. Till 2015, 566 RMC companies and 1135 RMC plants producing the $2733171 \mathrm{~m}^{3}$ of concrete per month. South India produces almost equal to 45 to 50 Even though India is third largest economy in asia and $6^{\text {th }}$ biggest industrialized nation in the world, however in the field of construction and practices India lags behind among developing countries [2]. A country development lots depending on infra structure and as

Revised Manuscript Received on December 30, 2019.

* Correspondence Author

A. Nagaraju*, Department of Civil Engineering, CMR Technical Campus, Medchal, India. Email: nagarajuavari@gmail.com

P. Sandeep Kumar, Department of Civil Engineering, CMR Technical Campus, Medchal, India. Email: nagarajuavari@gmail.com

M.Meena, Department of Civil Engineering, CMR Technical Campus, Medchal, India. Email: nagarajuavari@gmail.com

S. Vijaya Bhaskar Reddy, Department of Civil Engineering, CMR Technical Campus, Medchal, India. Email: nagarajuavari@gmail.com

(c) The Authors. Published by Blue Eyes Intelligence Engineering and Sciences Publication (BEIESP). This is an open access article under the CC BY-NC-ND license (http://creativecommons.org/licenses/by-nc-nd/4.0/) everyone knows concrete, is a quick preparing \% of the total commercial RMC in India and the commercial RMC Penetration is very high in south India compared to rest of India [3].

\section{Basic Concept of RMC}

IS: 4926-2003 defines ready mix concrete as concrete mixed in a stationary mixer in a central batching and mixing plant or in a truck mixer and supplied in a fresh condition to the purchaser either at site or into purchasers (vehicle) [4].There are two main types for production of concrete used in RMC plant. One is central mixed concrete plant and other is dry batch plant. In central mixed concrete plant, all ingredients are poured in fixed mixer, mix about 1min., then poured into truck mounted revolving mixer. By using power consumption evolution, water content was determined. It allows the water adjustments in truck. In dry mixing plant, all ingredients excepting admixture are poured into a buffer, which directly led them into the truck mounted revolving mixer that ensure both mixing and transport. In this delaying of admixture adding is due to estimate the dosage of admixture to get required flow ability. This method allows correcting the errors in water content by adjusting the admixture quantity into the truck. From the both the process, the basis of an annual production is of $40,000 \mathrm{~m}^{3} \mathrm{yr}^{-1}$. The additional mixer in a wet batch concrete plant is a $2 \mathrm{~m}^{3}$ mixer. Technically, it is showed that the addition of a mixer contributes to a better control of water proportion in the mixture [5]. In the case of a centrally mix type, the drum carrying the concrete revolves slowly so as to prevent the mixed concrete from ,segregation ${ }^{\text {ee }}$ and prevent its stiffening from initial set [6]. High rate of taxation on RMC plants, Land availability to establish RMC plants, Lack of education and training of industrial personnel, customer of RMC, City traffic and high ambient temperature, Long hauls and delivery and pumping ability of concrete pump are the major stumbling blocks for growth of RMC [7, 8].

\section{THE GROWTH OF RMC PLANTS}

From the year 2000, the growth of RMC plants was increasing. At present $85 \%$ of people opting for RMC. The major hurdles facing the RMC plants were heavy traffic, ambient temperature and pumping ability. However, advent of super plasticizers had a remarkable impact on growth of RMC's by retaining the slump without any setting delays. The cost per cubic meter of concrete will be different for different super plasticizer. For SNF, PCE, MPCE based super plasticizers the cost of concrete will be 5216, 5846 and 5416 respectively [10].

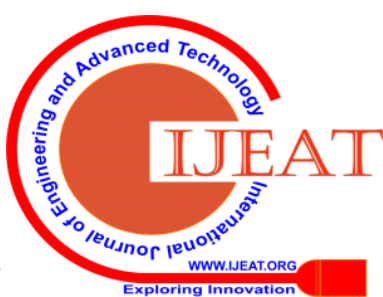




\section{Impact of Retention of Slump on Growth of Ready Mixed Concrete}

The growth of RMC plants was raised from the year of 2000. The concrete productions throughout India remarkably increased. In initial days RMC was established in metropolitan cities, then it reaches to urban cites and slowly it reaches to sub-urban cites.

No .of RMC plants in city wise in india

\begin{tabular}{|c|c|c|c|}
\hline Name of the city & $\begin{array}{l}\text { No. of plants (Appoxmately) } \\
2019\end{array}$ & $\begin{array}{c}\text { No. of plants } \\
\text { (Appoxmately) } 2014 \\
\text { (Vijay. R . Kulakarni } \\
\text { [6]) }\end{array}$ & Growth rate $(\%)$ \\
\hline Hyderabad & 49 & 15 & 2.27 \\
\hline Mumbai & 50 & 18 & 1.78 \\
\hline Bangalore & 30 & 25 & 0.20 \\
\hline Delhi & 29 & 28 & 0.04 \\
\hline chennai & 30 & 19 & 0.58 \\
\hline Kolkata & 22 & 9 & 1.44 \\
\hline Goa & 5 & 3 & 0.67 \\
\hline coiambatoor & 13 & 4 & 2.25 \\
\hline Nagpur & 12 & 2 & 5.00 \\
\hline Pune & 49 & 12 & 3.08 \\
\hline Mangalore & 6 & 2 & 2.00 \\
\hline manipal & 1 & 1 & 0.00 \\
\hline Vizag & 10 & 1 & 9.00 \\
\hline Vijayawada & 7 & 1 & 6.00 \\
\hline Hubli & 4 & 1 & 3.00 \\
\hline cochin & 8 & 4 & 1.00 \\
\hline surat & 10 & 4 & 1.50 \\
\hline Vadodara & 7 & 3 & 1.33 \\
\hline Ahemadabad & 11 & 8 & 0.38 \\
\hline Mysoor & 6 & 2 & 2.00 \\
\hline Jaipur & 16 & 3 & 4.33 \\
\hline Tri city & 8 & 1 & 7.00 \\
\hline Lucknow & 11 & 3 & 2.67 \\
\hline Ranchi & 9 & 1 & 8.00 \\
\hline Raipur & 10 & 1 & 9.00 \\
\hline
\end{tabular}

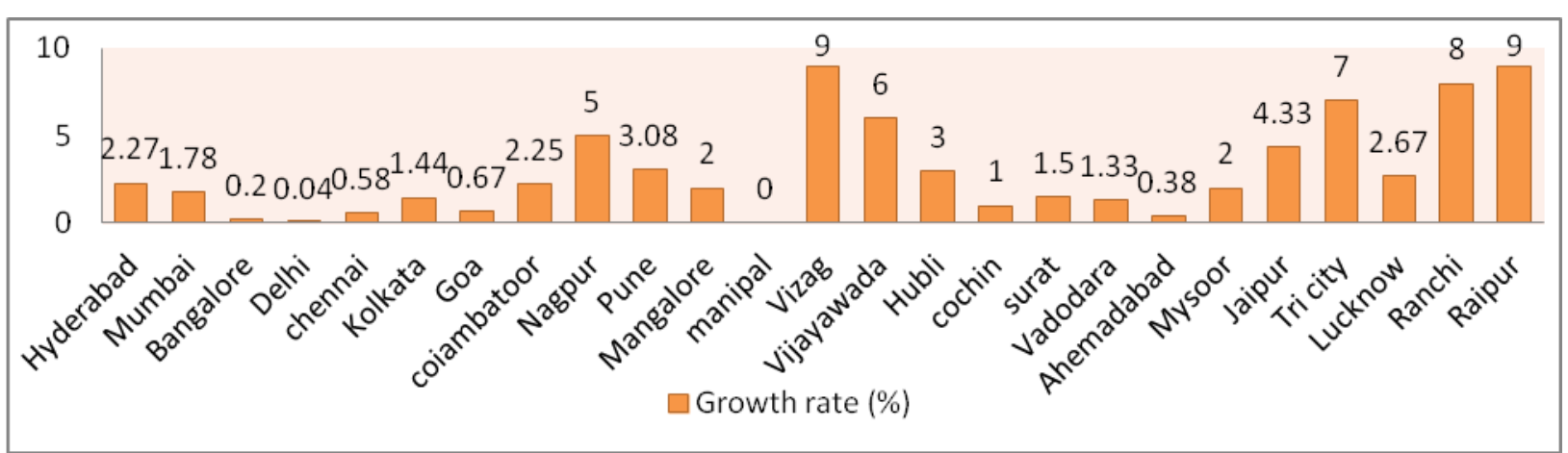

\section{II.EXPERIMENTAL INVESTIGATION}

The role of Slump retention capacity test in Ready mixed concrete:

In hot climates, at elevated ambient temperature, low humidity and under solar radiation or exposed to the wind, will increase the rate of evaporation of water and decrease the quality of concrete [10]. One of the major struggles of Ready mixed concrete is retention o f slump till construction site. Hence, therefore a accurate prediction has to be done not to lose the concrete mix. The slump test at certain intervals will make good prediction of retention capacity and also required dosage is also known by this test to retain the slump.
Admixture can be add initially or add at certain intervals. It noted that, separation of total SP into two can maintain the slump longer period as compared to the case of high initial slump, however there is no difference in strength [12].

In the present study, the influence of mineral admixture and influence of ambience temperature on slump retention capacity, a M30 grade of concrete made and slump cone test was conducted with different mineral admixtures like fly ash, GGBS, limestone powder. 


\section{MATERIALS Used}

\section{Cement:}

Normal consistency of cement is $34 \%$, finess of cement is 3grms, Specific gravity of cement is 2.94 \& soundness of cement is $7 \mathrm{~mm}$.

\section{Coarse aggregate:}

Fineness modulus of course aggregate is 7.145; Maximum size of aggregate 20 and specific gravity of aggregates is 2.8 .

\section{Fine aggregate}

Fineness modulus of Coarse aggregate is 2.4; Zone II sad and specific gravity of aggregates is 2.64 .

\section{Fly ash}

Fly ash, specific gravity is 2.9

\section{GGBS}

Specific gravity is 2.8

\section{Lime stone Powder}

Lime stone powder Specific gravity is 2.8

\section{CAC Admixture}

Mix details

\begin{tabular}{|c|l|l|c|c|}
\hline S.No & \multicolumn{1}{|c|}{ Material } & $\begin{array}{l}\text { Trial } \\
\text { mix-1 }\end{array}$ & Trial mix-2 & $\begin{array}{l}\text { Trial } \\
\text { mix-3 }\end{array}$ \\
\hline 1 & Cement $\left(\mathrm{kg} / \mathrm{m}^{3}\right)$ & 311.64 & 311.64 & 311.64 \\
\hline 2 & $\begin{array}{l}\text { Coarse aggregate } \\
\left(\mathrm{kg} / \mathrm{m}^{3}\right)\end{array}$ & 1125.43 & 1150.12 & 1167.07 \\
\hline 3 & $\begin{array}{l}\text { Fine aggregate } \\
\left(\mathrm{kg} / \mathrm{m}^{3}\right)\end{array}$ & 625.55 & 639.28 & 637.32 \\
\hline 4 & Fly ash $\left(\mathrm{kg} / \mathrm{m}^{3}\right)$ & 133.6 & - & - \\
\hline 5 & GGBS $\left(\mathrm{kg} / \mathrm{m}^{3}\right)$ & - & 133.6 & - \\
\hline 6 & Lime stone $\left(\mathrm{kg} / \mathrm{m}^{3}\right)$ & - & - & 133.6 \\
\hline 7 & CAC Super flow & 2.67 & 2.67 & 2.67 \\
\hline 8 & Water $\left(\mathrm{kg} / \mathrm{m}^{3}\right)$ & 200.37 & 200.37 & 200.37 \\
\hline
\end{tabular}

\section{RESULT AND DISCUSSION}

\begin{tabular}{|c|c|c|c|c|}
\hline S. NO & $\begin{array}{l}\text { SLUMP } \\
\text { VALUE }\end{array}$ & TIME & $\begin{array}{l}\text { CONCRETE } \\
\text { TEMP }\end{array}$ & $\begin{array}{l}\text { ROOM } \\
\text { TEMP }\end{array}$ \\
\hline 1 & Collapse & 11:55am & 19 & 23 \\
\hline 2 & $190 \mathrm{~mm}$ & $12: 25 \mathrm{pm}$ & 20 & 24 \\
\hline 3 & $170 \mathrm{~mm}$ & $12: 55 \mathrm{pm}$ & 20 & 24 \\
\hline 4 & $160 \mathrm{~mm}$ & $1: 25 \mathrm{pm}$ & 20 & 24 \\
\hline 5 & $130 \mathrm{~mm}$ & $1: 55 \mathrm{pm}$ & 19 & 24 \\
\hline 6 & $120 \mathrm{~mm}$ & 2:25 pm & 19 & 24 \\
\hline 7 & $90 \mathrm{~mm}$ & 2:55 pm & 20 & 24 \\
\hline
\end{tabular}

Table: Mix details

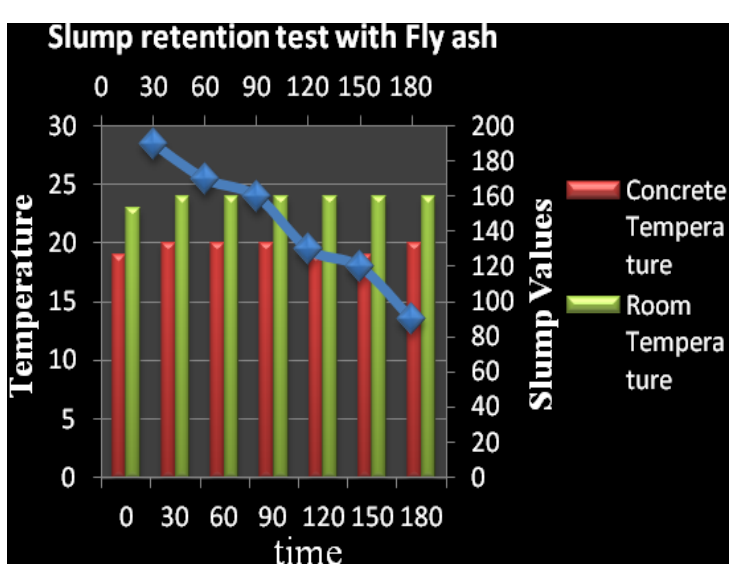

Graph: Slump retention capacity with Fly ash

With the fly ash, the slup was retain the wp to $180 \mathrm{~min}$. the rate of loss of slump is about $10 \%$. the concrete was maintain the temperature between the range of $19^{\circ}-20^{\circ} \mathrm{C}$

Table: Slump retention test with GGBS

\begin{tabular}{|r|l|l|c|c|}
\hline $\begin{array}{l}\text { S.N } \\
\text { o }\end{array}$ & $\begin{array}{l}\text { SLUMP } \\
\text { VALUE }\end{array}$ & TIME & $\begin{array}{l}\text { CONCRETE } \\
\text { TEMP }\end{array}$ & $\begin{array}{l}\text { ROOM } \\
\text { TEMP }\end{array}$ \\
\hline 1 & $210 \mathrm{~mm}$ & $9: 45 \mathrm{am}$ & 19 & 21 \\
\hline 2 & $150 \mathrm{~mm}$ & $\begin{array}{l}10: 15 \\
\text { am }\end{array}$ & 19.5 & 21 \\
\hline 3 & $95 \mathrm{~mm}$ & $\begin{array}{l}10: 45 \\
\text { am }\end{array}$ & 19 & 23 \\
\hline
\end{tabular}



Graph: Slump retention test with GGBS

With GGBS, the slump was retained upto 1 hour. The rate of slump is about $25 \%$. The concrete temperature maintained about $19^{\circ} \mathrm{C}$.

Table: Slump retention test with Lime stone Powder

\begin{tabular}{|r|c|l|l|c|}
\hline $\begin{array}{l}\text { S. } \\
\text { NO }\end{array}$ & $\begin{array}{l}\text { SLUMP } \\
\text { VALUE }\end{array}$ & TIME & $\begin{array}{l}\text { CONCRETE } \\
\text { TEMP }\end{array}$ & $\begin{array}{l}\text { ROOM } \\
\text { TEMP }\end{array}$ \\
\hline 1 & $170 \mathrm{~mm}$ & $\begin{array}{l}12: 50 \\
\text { pm }\end{array}$ & 21 & 26 \\
\hline 2 & $85 \mathrm{~mm}$ & $1: 20 \mathrm{pm}$ & 20 & 27 \\
\hline
\end{tabular}






Graph: Slump retsention test with lime stone powder

With lime stone Powder, the slump was retained upto 30min hour. The rate of loss of slump is about $40 \%$. The concrete temperature maintained about $19^{\circ} \mathrm{C}$.

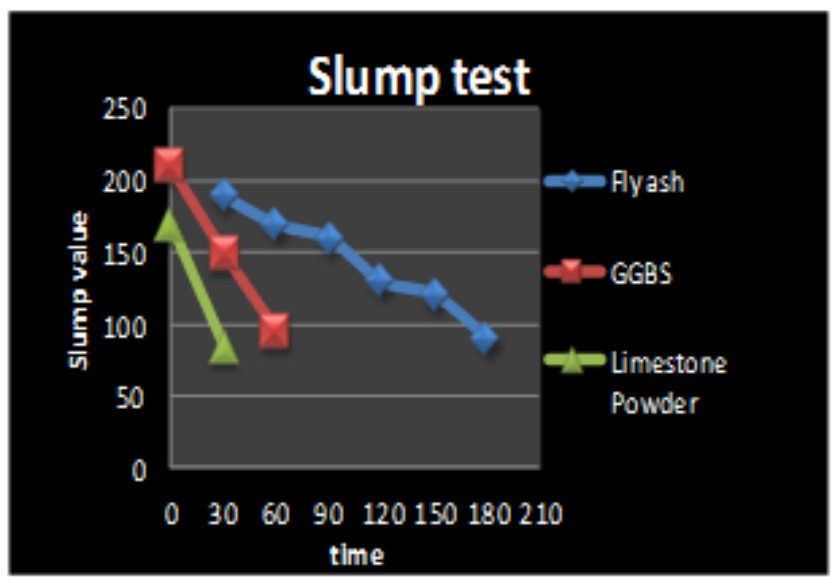

Graph: Slump test

\section{Compressive Test}

The compressive test was done in Compression testing Machine (capacity of $2000 \mathrm{kN}$ ) . with fly ash , $19 \mathrm{Mpa}$ strength was achieved. With GGBS and lime stone powder the strength was reached up to $35 \mathrm{Mpa}$ and reached the target mean strength.

\begin{tabular}{|c|c|c|c|c|}
\hline $\begin{array}{c}\text { Replaced } \\
\text { material }\end{array}$ & Trail & 3-days & 7-days & 28-days \\
\hline \multirow{4}{*}{$\begin{array}{c}\text { With Fly } \\
\text { ash }\end{array}$} & T1 & 11.33 & 14.39 & 18.09 \\
\cline { 2 - 5 } & T2 & 11.56 & 15.01 & 18.59 \\
\cline { 2 - 5 } & T3 & 11.45 & 14.89 & 20.51 \\
\cline { 2 - 5 } & Average & 11.45 & 14.76 & 19.06 \\
\hline \multirow{4}{*}{$\begin{array}{c}\text { With } \\
\text { GGBS }\end{array}$} & T1 & 20.70 & 24.36 & 34 \\
\cline { 2 - 5 } & T2 & 20.80 & 25.79 & 36.68 \\
\cline { 2 - 5 } $\begin{array}{c}\text { Wimestone } \\
\text { powder }\end{array}$ & T3 & 20.51 & 25.87 & 37.15 \\
\cline { 2 - 5 } & Average & 20.67 & 24.35 & 35.94 \\
\cline { 2 - 5 } & T1 & 15.79 & 26.58 & 30.79 \\
\cline { 2 - 5 } & T3 & 16.78 & 22.89 & 31.87 \\
\cline { 2 - 5 } & Average & 16.45 & 24.50 & 32.48 \\
\hline
\end{tabular}

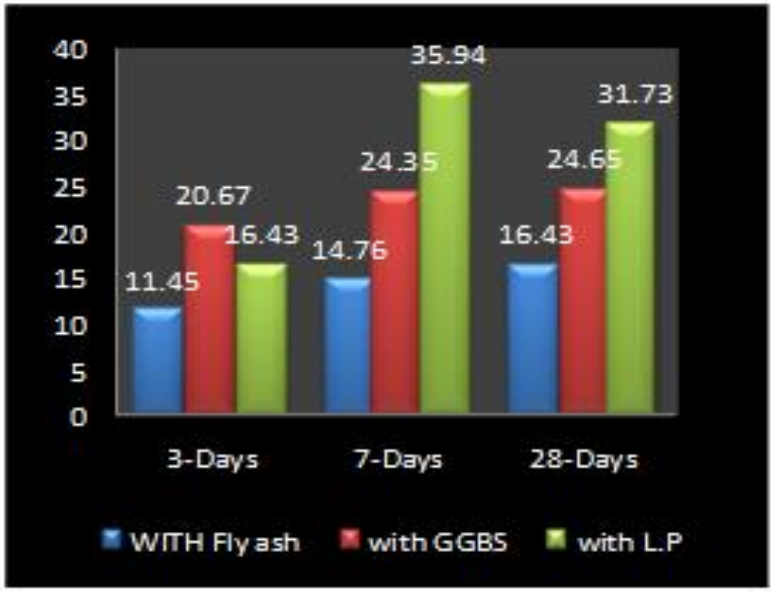

\section{CONCLUSION}

1. The cities like vizag, nagpur, ranchi, tricity were shown that a tremdous growth of RMC plnats. The growth rate was reached upto $9 \%$. The overal growth rate was $58 \%$ and cummulative growth rate is $65 \%$. Hence, a huge growth was taken place in through out india in recent times.

2. From the experimental study, the trial mix with fly ash, GGBS, lime stone Powder slump retained about 3 hours, 1.5 hours, 1 hour with $0.6 \%$ of super plasticizer dosage.

3. A part from the admixtures effect, temperature was also shown a remarkable influence on slump retention capacity. For trial mix 2,3 the concrete temperature was higher than trial mix 1, Hence with in short time slump value was reduced.

4. The concrete temerature with the all the replaced material is about $19^{\circ} \mathrm{C}$.

5. the 28-days strengh value, with GGBS and Limestone powder is higher than the with flyash.

6. Only the with GGBS, the concrete achieved the target mean stngth.

7. From the above the tests, the concrete performance with GGBS given satisfactory results.

\section{REFERENCES}

1. Tarek UddinMohammed, Tanvir Ahmed, Shibly Mostafiz Apurbo, Tahir Absar Mallick,Farhan Shahriar, Abdul Munim, Mohammad Abdul Awal, Influence of Chemical Admixtures on Fresh and Hardened Properties of Prolonged Mixed Concrete, Hindawi ,Advances in Materials Science and Engineering, Volume 2017, Article ID 9187627, 11 pages.

2. D.Gordon, P. Kshemendranath, setting up of Ready Mix concrete industry in India, international conference, Dundee, Sept 99.

3. Manjunatha L R, Sandhya R Anvekar, "History of ready-mixed concrete in India", ABBS Management Business and Entrepreneurship Review, Volume: 6 Issue: 1 October 2014 - March 2015 ISSN: 0976 - 3341.

4. Rahul Kumar, Dr. J.P. Tegar, "Critical Analysis of Properties of Ready Mix Concrete with Site Mix Concrete of Smart Road Project", International Research Journal of Engineering and Technology, Volume: 05 Issue: 06, June-2018, e-ISSN: 2395-0056.

5. Bogdan Cazacliu, Anne Ventura, "Technical and environmental effects of concrete production: dry batch versus central mixed plant" Journal of Cleaner Production 18 (2010) 1320-1327.

6. Vijaykumar R Kulkarni, "Evolution of RMC in India”, The Master builder - July 2012. 
7. Rahul Mahajan, Reuben Buthello, "Quality Control of Ready Mixed Concrete", IOSR Journal of Mechanical and Civil Engineering, Volume 12, Issue 5 Ver. V (Sep. - Oct. 2015), PP 01-07, e-ISSN: 2278-1684,p-ISSN: 2320-334X.

8. Sohail Afzal, Zishan Raza Khan, "A Review Paper on Factors Affecting Ready- Mix Concrete Delivery Pattern", International Journal of Construction Engineering and Management 2018, 7(3): 97-100.

9. TableEvangeline.K , Dr.M.Neelamegam, "Effect of Superplasticizer on Workability and Mechanical Properties of Self-Compacting Concrete", IOSR Journal of Mechanical and Civil Engineering, e-ISSN: 2278-1684, p-ISSN: 2320-334X, PP 18-29.

10. Nabil Bella, Ilham Aguida Bella , and Aissa Asroun "A review of hot climate concreting, and the appropriate procedures for ordinary jobsites in developing countries", MATEC Web of Conferences 120, 02024 (2017) ,ASCMCES-17,

11. R. H Dhakal , C. Wanichlamlert 2 "Slump Retention of Concrete by Time Splitting of Superplasticizer Dose" 1 School of Civil Engineering and Technology, Sirindhorn International Institute of Technology, Thammasat University,2014.

\section{AUTHORS PROFILE}

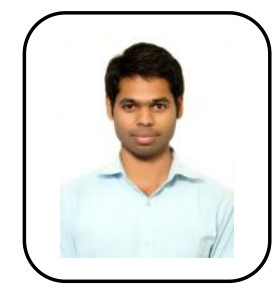

Nagaraju. A, is currently working as Assistant Professor in CMR Technical campus. He had completed. B.Tech in RGUKT-Basar, in 2014 and he had perused M.E degree from CBIT, in 2017. He had taken member ship in ISTE. He had published 3 research papers.



P. Sandeep Kumar, is currently working as Assistant Professor in CMR Technical campus. He had completed. B.Tech in RGUKT-Basar, in 2014 and he had perused M.E degree from CBIT, in 2017. He had taken member ship in ISTE. He had published 3 research papers



M.Meena, is currently working as Assistant Professor in CMR Technical campus. She completed. B.Tech in Jayaprakash Narayana college of Engineeirng, Mahaboonagar, in 2013 and completed $M$. tech from Kasi reddy Narayana Reddy college of Engineering, in 205. He had taken member ship in ISTE. He had published 3 research papers.

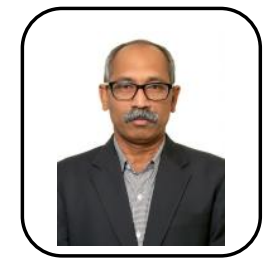

S. Vijaya Bhaskar Reddy, Professor and Head of Civil Engineering Department in CMR Technical campus, Hyderabad. Specialized in structural Engineering, having 15 year Academic and 6 years research experience, and published 20 research papers. Research interests are Concrete Technology, Blended concretes, Earthquake Resistance Design of structures, and life time Member of ISTE, Fellow Member of Institution of Engineering, Member Indian Society of Earth Quake Technology, Member Indian concrete Institute. 